\title{
Paclitaxel and Cisplatin Combination Chemotherapy in Pretreated Breast Cancer
}

\author{
Joo Hyuk Sohn, M.D. ${ }^{1,2,3}$, Yong Tai Kim, M.D..$^{1,2,3}$, Sun Young Rha, M.D., Ph.D. ${ }^{1,2,3,4}$, Nae Choon Yoo, \\ M.D., Ph.D. ${ }^{1,2,3}$, Jae Kyung Roh, M.D., Ph.D. ${ }^{1,2,3,4}$, Byung Soo Kim, M.D., Ph.D. ${ }^{2}$, Chang Ok Suh, M.D., \\ Ph.D. ${ }^{2}$, Gwi Eon Kim, M.D., Ph.D. ${ }^{2}$, Woo Ick Jang, M.D., Ph.D. ${ }^{5}$ and Hyun Cheol Chung, M.D., Ph.D. ${ }^{1,2,3,4}$ \\ Department of ${ }^{1}$ Internal Medicine, ${ }^{2}$ Yonsei Cancer Center, ${ }^{3}$ Cancer Metastasis Research Center and ${ }^{4}$ Brain Korea 21 Project \\ for Medical Science, Yonsei University College of Medicine; ${ }^{5}$ Lilly Korea, Ltd., Seoul, Korea
}

Purpose: A single institute trial of combination chemotherapy, with paclitaxel and cisplatin, in patients with metastatic breast cancer, having failed previous combination chemotherapy, was performed.

Materials and Methods: Patients were only eligible for this study if there disease had progressed, following treatment with previous chemotherapy, in either an adjuvant or a metastatic setting. Paclitaxel $175 \mathrm{mg} / \mathrm{m}^{2}$ was administered as a 3 -hour continuous infusion on day 1 , and cisplatin $80 \mathrm{mg} / \mathrm{m}^{2}$ was administered for 2 hours on day 2 , with adequate hydration. This was repeated every 3 weeks, and continued until one of the following events occurred: disease progression, unacceptable adverse effect or treatment refusal by the patient. Intercurrent palliative radiotherapy, or concurrent hormonal therapy, was permitted, depending on each patient's status. All the endpoints were evaluated under the principle of intention to treat analysis.

Results: A total of 24 patients entered the study, and $18 \mathrm{had}$ at least one measurable lesion, but 6 did not. The objective response rate of the 18 patients was $50 \%$

\section{서 론}

유방암은 우리나라 여성에서 두 번째로 많은 암으로 보 고되고 있으며(1), 조기검진, 근치적 수술, 보조 항암제, 보 조 호르몬 치료 및 방사선 치료에도 불구하고 $40 \%$ 의 환자 에서 전이성 재발을 하는 암이다(2).

이러한 전이성 유방암 환자에서는 호르몬 치료가 1차 치

Correspondence: Hyun Cheol Chung, Yonsei Cancer Center, Yonsei University College of Medicine, 134 Sinchon-dong, Seodaemun-gu CPO Box 8044, Seoul 120-752, Korea. (Tel) 82-2-393-3652, (Fax) 82-2-393-3652, (E-mail) unchung8@yumc.yonsei.ac.kr

Received February 17, 2003, Accepted May 7, 2003

The Korean Science and Engineering Fund through the Cancer Metastasis Research Center at Yonsei University supported this work.
(9/18). Two were complete responses and seven showed partial responses. The median response duration, progression free and overall survival were 5.3 months (range, $4 \sim 18), 6$ months $(95 \% \mathrm{Cl}, 5 \sim 7)$ and 12 months $(95 \% \mathrm{Cl}, 7 \sim 17)$, respectively. $67 \%$ of the planned dose was administered. Out of a total 135 cycles administered, about $20 \%$ of cycles showed grade 3 or 4 leukopenia and $7 \%$ showed grade 3 thrombocytopenia. Two patients suffered from pneumonia, and one experienced neutropenic fever. Mucositis, greater than grade 3 , existed in three cases. No treatment related deaths were reported.

Conclusion: The combination chemotherapy, with paclitaxel and cisplatin, was active in the treatment of metastatic breast cancer patients having failed previous chemotherapy. (Cancer Research and Treatment 2003;35:267-273)

Key Words: Breast neoplasm, Salvage, Chemotherapy, Paclitaxel, Cisplatin

료로 권유되고 있으며, 호르몬 수용체가 음성이거나, 내부 장기로 전이되어 있는 경우, 혹은 진행 속도가 빨라 생명을 위협할 수 있는 경우에는 일차적으로 항암제 치료가 시행 된다. 전이성 유방암에서 가장 효과적인 약으로는 anthracycline과 taxane 계열(paclitaxel, docetaxel)이 알려져 있다.

Taxane은 단일 약제로 전이성 유방암에서 anthracycline이 포함되지 않는 복합 항암제 치료보다 생존기간을 연장시키 는(3,4) 효과적인 약제이며 taxane 단독치료가 anthracycline 과 taxane 복합치료와 비교하여 생존기간에 차이가 없어서 (5 7), 현재는 전이성 유방암에서 anthracycline 치료 후 실 패한 환자에서 taxane 사용이 널리 시행되고 있다.

복합항암제 치료는 작용 기전이 다른 두 종류 이상의 약 제를 사용함으로써, 약제 저항성 암세포의 출현을 줄일 수 있고, 적절한 용량을 사용함으로써 반응률을 높이고 독성 
을 줄이는 장점이 있다. 이러한 반응률의 증가는 종양으로 인한 증상들을 감소시키고, 생존율의 증가와 삶의 질의 향 상을 유도할 것으로 기대된다. 이에 따라 taxane에 vinca alkaoid, 대사 길항제, platinum 등이 병합되어 치료가 시행 되었다.

전이성 유방암에서 Platinum에 대한 임상 연구는 많이 시 행되지 않았다. Cisplatin 단독치료를 일차요법으로 사용 시 에는 반응률이 50\% (33/66)이었지만 구제요법으로서, 즉, 첫번째 항암제 치료 실패 후 사용 시에는 9\% (10/113)의 반 응률이 보고되고 있다(8). 하지만, 전이성 유방암에서 단독 으로는 효과가 미미하다고 알려진 etoposide와 platinum의 병용 치료는 CMF (Cyclophosphamide, Methotrexate, 5-Fuorouracil) 병용 치료와 비교한 3상 연구에서 $\mathrm{CMF}$ 요법보다 유 의하게 반응률이 높았다(63\% vs $48 \%)(9)$. 이와 같이 cisplatin은 이차약제로 사용 시에는 반응률이 일차약제로 사 용할 때와 비교하여 현저히 떨어지며, 충분치 않는 문헌의 보고에도 불구하고 anthracycline, taxane에 이어서 세 번째로 효과 있는 약제라고 보고되고 있다. 이러한 배경하에, anthracycline이 보조 약물 치료제로 혹은 전이성 암에 대한 일 차약제로 이미 사용된 환자들에게 cisplatin을 taxane과 병용 하여 투여 시의 효과와 부작용을 평가하고자 하였다.

\section{대상 및 방법}

\section{1) 대상}

1993년 4월부터 1998년 11월까지 연세대학교 의과대학 세브란스병원, 연세 암센터에 유방암으로 내원한 환자 중 근치적 치료와 보조 항암화학요법 후 재발하였거나, 진단 당시 이미 전이성 병변으로 anthracycline 계열의 항암 화학 요법을 시행하였으나 병변이 진행된 환자를 대상으로 하였 다. 대상 환자의 선정 기준은 조직학적으로 유방암이 진단 된 환자로서, 조직학적 혹은 방사선학적으로 증명된 전이 성 병변이 있고, 일상생활 수행능력이 ECOG기준으로 0 2 인 환자들이었다. 연령은 18 세 이상 70 세 이하이며, 적절한 골수, 간, 신기능(혈색소 $10 \mathrm{~g} / \mathrm{dl}$, 호중구 $1,500 / 1$, 혈소판 $100,000 / 1$, 총빌리루빈과 크레아티닌은 정상 상한치의 1.5 배 미만, AST/ALT는 정상 상한치의 2배 미만)를 갖는 경우로 하였다. 모든 환자는 항암약물 치료 전에 치료에 관한 설명 을 듣고 서면으로 동의서를 제출하였다.

\section{2) 치료계획}

치료는 paclitaxel $175 \mathrm{mg} / \mathrm{m}^{2}$ 을 3시간 동안 정주하였고 모 든 환자들은 경구 dexamethasone $20 \mathrm{mg}$ 을 항암 치료 12시간 전과 6 시간 전에 전처치로 복용하였다. Diphenhydramine 50 $\mathrm{mg}$ 과 cimetidine $300 \mathrm{mg}$ 도 항암 치료 30 분 전에 정주하였다. Paclitaxel 투여 후 cisplatine $80 \mathrm{mg} / \mathrm{m}^{2}$ 을 2시간 동안 적절한 수액과 함께 정주하였다.

3 주 간격으로 항암화학요법을 시행하였고, 진행성 병변 을 보이는 경우, 중증의 독성을 보이는 경우 및 환자가 투약 중지를 원하는 경우에는 투여를 종료하였다. 그렇지 않는 경우에는 최대 9주기까지 약물치료를 시행하였다. 호르몬 수용체가 양성인 경우와 음성이라도 paclitaxel과 cisplatin 항암 화학요법 시작 시 무월경인 경우는 폐경으로 간주하 여 호르몬 치료를 항암제와 병용 투여하였다. G-CSF는 치 료적 목적으로, 그리고 지난 주기에서 3 도 혹은 4 도의 백혈 구 감소증을 보였을 시에는 다음주기에서 예방적 목적으로 사용하였다.

\section{3) 치료 전 평가 및 추적 관찰}

첫 항암 치료 시작 2 주 전과 매 주기 항암치료 시작 전 모든 환자들은 병력청취, 신체검사, 일반 혈액검사, 일반 혈 청화학검사, 일반 뇨검사, 흉부 X-선 검사 및 심전도 검사를 시행하였다. CT 등의 측정 가능한 혹은 평가 가능한 병변을 증명할 방사선학적 검사는 치료시작 4 주 이내에 시행되었 고 3 주기마다 같은 검사가 반복되어 종양 반응 평가에 이용 되었다. 종양 평가 결과 부분반응 혹은 완전반응인 경우는 4 주 후 같은 검사를 다시 시행하여 반응을 확정하였다.

\section{4) 종양 반응 평가 및 독성 평가}

환자들은 계측 가능한 병변을 갖는 환자와 그렇지 않고 골전이, 악성 향막액, 악성복수 등의 평가 가능한 병변만을 갖는 환자로 구분하여 계측 가능한 병변을 갖는 환자에서 반응 평가가 이루어졌고 평가 가능한 병변을 갖는 환자들 은 생존분석 및 독성 평가에 포함되었다.

완전반응은 임상적으로 암 병소가 모두 소실되고 새로운 병변의 출현이 없는 경우, 부분반응은 계측 가능한 병변의 크기가 $50 \%$ 이상 감소되고, 기타 병소의 악화나 새로운 병 변의 출현이 없는 경우, 불변은 계측 가능한 병변의 크기가 $50 \%$ 미만의 감소 또는 $25 \%$ 미만의 증가를 보이면서 새로 운 병변의 출현이 없는 경우, 그리고 진행성 병변은 계측 가능한 병변의 크기가 $25 \%$ 이상 증가하거나 새로운 병변이 출현한 경우로 정의하였다. 치료 반응은 치료시작부터 병 의 진행 또는 연구 종료에 이르기까지 기록된 최상의 반응 으로 하였다. Taxol과 cisplatin이 몇 번째 항암치료로 사용 되었는가에 따라, 그리고 전 항암제 치료 후 6 개월이 지났 는가 아닌가에 따라 구분하여 반응률을 조사해 보았다. 항 암제에 의한 독성은 $\mathrm{WHO}$ 독성기준에 의해 평가하였다. 


\section{5) 생존분석 및 용량강도와 예후인자 분석}

질병 진행까지의 기간은 치료 시작으로부터 질병의 진행 이 관찰되거나 사망까지의 기간으로 정의하였으며 전체생 존기간은 치료 개시일부터 환자 사망일 또는 마지막 추적 일까지로 하였다. 반응기간은 치료 반응을 보인 환자에서 반응이 확인된 시점에서 병변의 진행이 확인된 시점까지로 하였다. 질병진행까지의 기간, 전체생존기간은 KaplanMeier방법을 이용하여 분석하였다. 용량강도는 단위시간에 투여된 약제의 용량으로 단위는 $\mathrm{mg} / \mathrm{m}^{2} / \mathrm{wk}$ 로 표시하였다. 실제 투여된 용량강도를 실제용량강도(Actual dose intensity, $\mathrm{ADI}$ 라 하고, 상대용량강도(Relative dose intensity, RDI)는 실제 투여된 용량과 계획하였던 용량의 비로 구하였다. 마 지막으로 무진행 생존기간 및 전체 생존기간과 관련된 예 후 인자 분석을 실시하였다. 예후 인자 분석에 Log rank test 와 Cox regression analysis를 이용하였다.

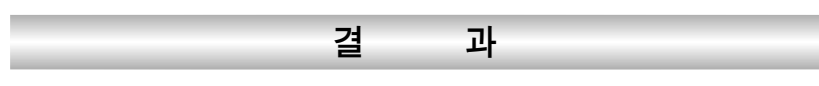

\section{1) 대상 환자의 특성}

대상 환자 24 명 중 18 명은 계측 가능한 병변이 있어 반응 평가가 가능하였고 6 명은 평가 가능한 병변만을 가지고 있 어 생존 분석 및 독성에 대한 평가만이 가능하였다. 연령 분포는 $28 \sim 66$ 세로 중앙값은 49세였다. 일상 생활 수행능 력은 $\mathrm{ECOG}$ 기준 0 1이 23명 2가 1명이었다. 항암치료 시 작 시 월경상태는 폐경기 이전 3 , 폐경 중 2 , 그리고 폐경기 이후는 19 명이었다. 호르몬 수용체에 대한 조사는 총 21 명 에서 가능하여 $\mathrm{ER}$ 양성 4명, $\mathrm{ER}$ 음성 17 명이었고 $\mathrm{PR}$ 양성 9 명 PR음성 12명이었다. Her-2/neu 수용체는 5명(양성 3, 음 성 2)에서만 조사가 가능하였다. 전이병소는 골전이 11 명 (46\%)과 림프절 전이 12 명 $(50 \%)$ 이 가장 많은 빈도였다.

환자의 79\% (19/24)에서 anthracycline을 항암제 보조 약물 치료로서 혹은 전이성 유방암에 대한 1차 치료로서 투여

Table 1. Patient characteristics in 24 treated patients

\begin{tabular}{|c|c|c|c|c|c|}
\hline & No. & $\%$ & & No. & $\%$ \\
\hline Enrolled patients & 24 & 100 & Metastatic sites & & \\
\hline Disease status & & & Breast/Chest wall & 6 & 25 \\
\hline Measurable & 18 & 75 & Contralateral breast & 3 & 13 \\
\hline Evaluable & 6 & 25 & Lymph node & 12 & 50 \\
\hline Performance status & & & Bone & 11 & 46 \\
\hline 0 & 6 & 25 & Lung & 6 & 25 \\
\hline 1 & 17 & 71 & Liver & 4 & 17 \\
\hline 2 & 1 & 4 & Pleura & 6 & 25 \\
\hline Pathology & & & Other & 1 & 4 \\
\hline Ductal & 22 & 92 & & & \\
\hline Lobular & 1 & 4 & Pre-taxol treatment & & \\
\hline Unknown & 1 & 4 & Adjuvant. CTx* & & \\
\hline Estrogen receptor & & & $\mathrm{ADR}^{\dagger}$ based & 12 & 50 \\
\hline Positive & 4 & 17 & Non ADR based & 5 & 21 \\
\hline Negative & 17 & 71 & Palliative $\mathrm{CTX}^{*}$ (ADR based) & 7 & 29 \\
\hline Unknown & 3 & 12 & Metastasis site number & & \\
\hline Progesterone receptor & & & One & 8 & 33 \\
\hline Positive & 9 & 37 & Two & 11 & 46 \\
\hline Negative & 12 & 50 & Three & 2 & 8 \\
\hline Unknown & 3 & 13 & More than three & 3 & 13 \\
\hline Her-2/neu & & & Concomittent radiotherapy & & \\
\hline Positive & 3 & 13 & Yes & 8 & 33 \\
\hline Negative & 2 & 8 & No & 16 & 67 \\
\hline Unknown & 19 & 79 & Concomittent hormone therapy & & \\
\hline Menstruation & & & Yes & 15 & 63 \\
\hline Pre-menopause & 3 & 13 & No & 9 & 37 \\
\hline Peri-menopause & 2 & 8 & Age & & \\
\hline Post-menopause & 19 & 79 & Median (Range) & $49(28 \sim 66)$ & \\
\hline
\end{tabular}

*Chemotherapy, ${ }^{\dagger}$ Adriamycin 
받았었다. Paclitaxel과 cisplatin이 2차 약제로 사용된 환자가 18 명 $(75 \%), 3$ 차 약제로서가 4명(17\%), 그리고 4차 약제로서 가 2 명 $(8 \%)$ 였다. 항암제 치료와 동시에 방사선 치료를 받았 던 환자는 8 명 $(33 \%)$, 호르몬 치료를 동시에 받았던 환자는 15명(63\%)이었다(Table 1).

Table 2. Response summary

\begin{tabular}{clc}
\hline Response & No. & $\%$ \\
\hline CR & 2 & 11 \\
PR & 7 & 39 \\
SD & 5 & 28 \\
PD & 3 & 17 \\
No response evaluation & 1 & 5 \\
Response rate & $9 / 18$ & 50 \\
\hline Response duration & 5.3 months (range, $4 \sim 18)$ \\
\hline
\end{tabular}

\section{2) 치료반응 및 생존율}

계측 가능한 병변을 갖는 18 명의 환자 중 2 명 $(11 \%)$ 은 완 전반응, 7 명(39\%)은 부분반응으로 전체 반응률은 $50 \%$ 이었 다(Table 2). 반응기간의 중앙값은 5.3개월(범위 4 18)이었 다. 완전반응이 유도된 환자 2 명은 림프절에만 전이가 있었 다. Taxol과 cisplatin은 이차약제로 사용되었던 경우와 전의 항암치료와의 간격이 6개월을 넘었던 경우가 반응률이 좋 은 경향을 보였다(Table 3). 전체 환자 24 명의 진행정지 기 간의 중앙값은 6 개월 $(95 \%$ CI $5 \sim 7$ 개월)이며 전체 생존기간 의 중앙값은 12 개월 $(95 \%$ CI 7 17개월)이었다(Fig. 1). 연구 종료시점에서 24 명 중 21 명이 사망하였다.

\section{3) 용량강도 및 독성}

대상 환자 24명의 환자에게 총 135 주기의 약물 투여를 시 행하였으며, 치료 주기의 중앙값은 6주기(2 9주기)이었다.

Table 3. Response rates according to taxol and cisplatin line and interval from previous chemotherapy

\begin{tabular}{|c|c|c|c|c|c|}
\hline \multirow{2}{*}{ Response } & \multicolumn{3}{|c|}{ Taxol \& cisplatin line } & \multicolumn{2}{|c|}{ Last $\mathrm{CT}^{*}$ before taxol } \\
\hline & $2^{\text {nd }}(n=14)$ & $3^{\text {rd }}(n=3)$ & $4^{\text {th }}(n=1)$ & $6 \mathrm{mo} . \leq$ & $>6 \mathrm{mo}$ \\
\hline $\mathrm{CR}^{+}$ & 1 & 1 & 0 & 1 & 1 \\
\hline $\mathrm{PR}^{\ddagger}$ & 7 & 0 & 0 & 1 & 6 \\
\hline $\mathrm{SD}^{\S}$ & 3 & 2 & 0 & 4 & 1 \\
\hline $\mathrm{PD}^{\|}$ & 2 & 0 & 1 & 3 & 0 \\
\hline No response evaluation & 1 & 0 & 0 & 1 & 0 \\
\hline Response rate & $57 \%(8 / 14)$ & $33 \%(1 / 3)$ & $0 \%(0 / 1)$ & $20 \%(2 / 10)$ & $88 \%(7 / 8)$ \\
\hline
\end{tabular}

${ }^{*}$ Chemotherapy, ${ }^{\dagger}$ Complete response, ${ }^{\ddagger}$ Partial response, ${ }^{\S}$ Stable disease, "Progressive disease
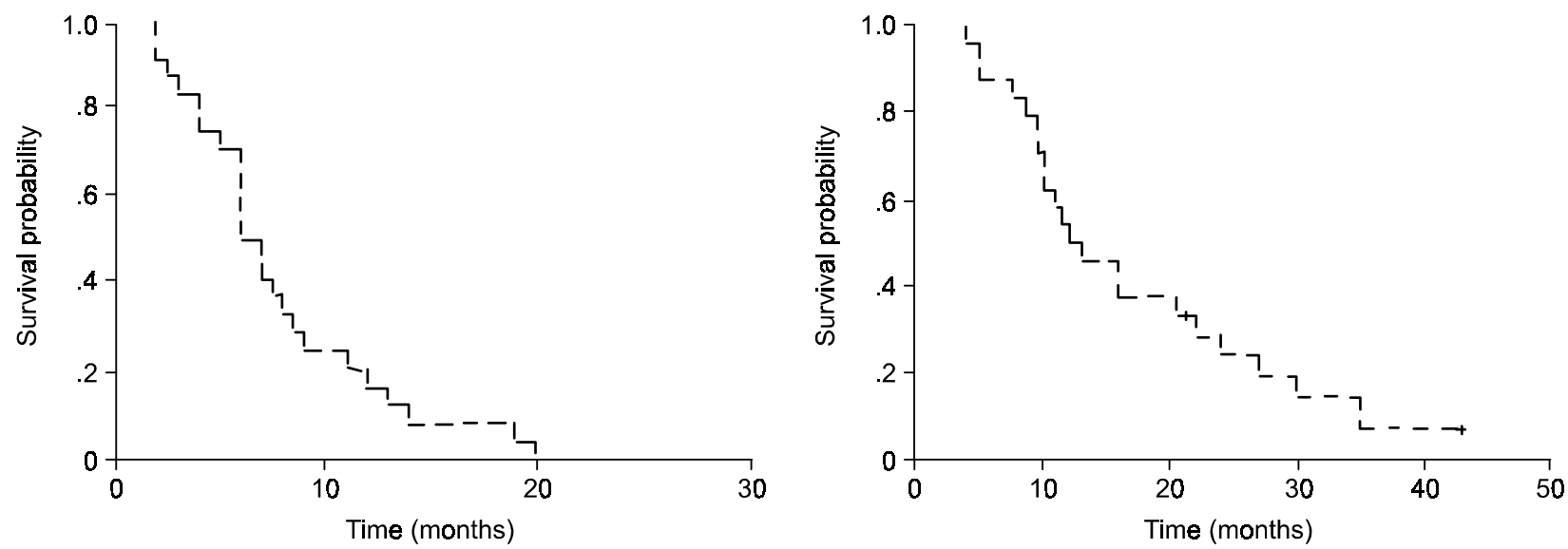

Fig. 1. Progression free and overall survival curves of the 24 patients with median survival of 6 month (95\% CI 5 7 months) and 12 months (95\% CI 7 17 months), respectively. 


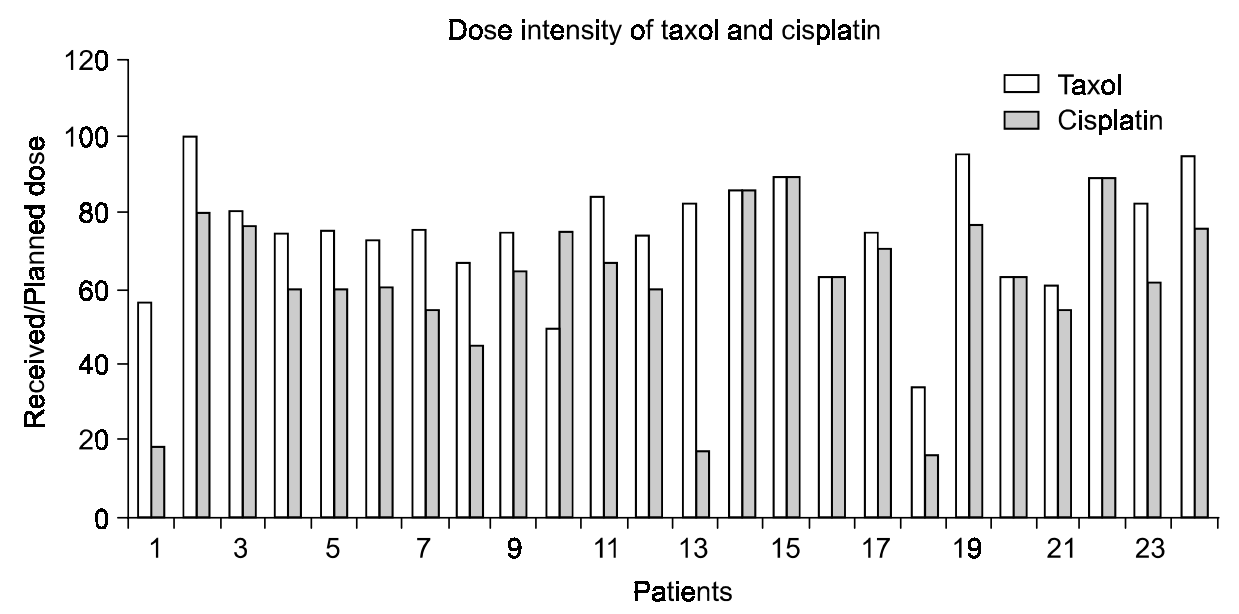

Fig. 2. Dose intensity of paclitaxel and cisplatin of all the patients.

Table 4. Hematologic toxicity

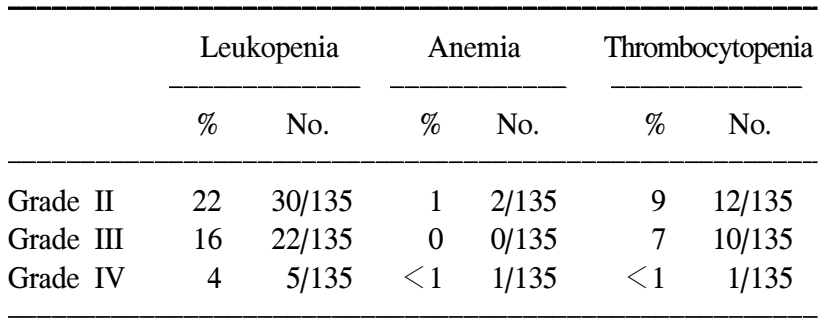

9회의 용량감소가 있었고 63 주기에서 항암 치료가 연기되 었다. Paclitaxel의 상대 용량강도의 중앙값은 0.75 (범위 $0.34 \sim 1.00$ )이었고 실제 용량강도의 중앙값은 $37.5 \mathrm{mg} / \mathrm{m}^{2}$ / wk (범위 $16.9 \sim 50.0 \mathrm{mg} / \mathrm{m}^{2} / \mathrm{wk}$ )이었다. Cisplatin의 상대 용 량강도의 중앙값은 0.63 (범위 $0.16 \sim 0.89$ )이었고 실제 용량 강도의 중앙값은 $20.9 \mathrm{mg} / \mathrm{m}^{2} / \mathrm{wk}$ (범위 $4.8 \sim 29.6 \mathrm{mg} / \mathrm{m}^{2} / \mathrm{wk}$ ) 이었다(Fig. 2).

전체 투여된 135 주기의 항암치료 중 $20 \%$ 에서 3 도 혹은 4 도의 백혈구 감소증이 있었고 $7 \%$ 에서 3 도 혹은 4 도의 혈 소판 감소증이 있었다(Table 4). 두 명의 환자는 치료 중 폐 렴을 경험하였고 한 명은 호중구 감소성 발열이 있었으나 적절한 치료로 회복되었다. 대부분의 환자에서 1 2도의 오심, 구토, 점막염을 호소하였으나, 항구토제와 보존적 치 료로 조절 가능하였다. 3 도 이상의 점막염은 3 명의 환자에 서 있었고 3 도 이상의 오심 구토를 호소하는 화자도 한명 있었다. 2 명의 환자가 각각 2 도와 3 도의 설사를 호소하였으 나 지사제와 보존적 요법으로 조절 가능하였다. 근육통이 나 관절통은 25\% (6/24)에서 그리고 신경염은 $21 \%(5 / 24)$ 에 서 호소하였으나 대부분 1 2도로 적절한 치료로 호전되었 다. 신장 독성은 관찰되지 않았고 치료와 관련된 사망도 없 었다. 한 명의 환자가 2 주기의 항암제 치료 후 폐색전증으 로 사망하였다.
Table 5. Prognostic factors for progression free and overall survival

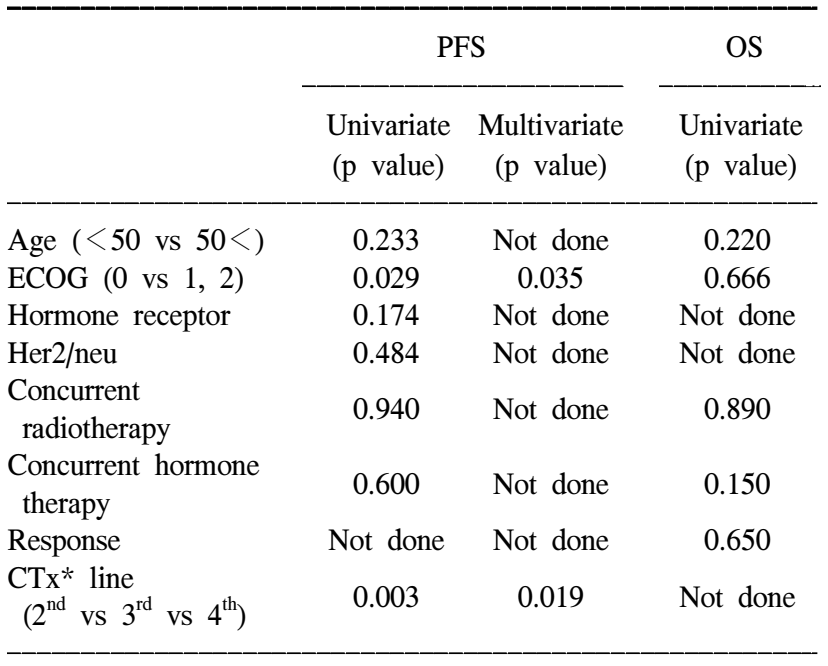

*Chemotherapy

\section{4) 예후인자 분석}

단변량 그리고 다변량 분석상, 환자의 수행 정도가 좋을 수록 그리고 paclitaxel과 cisplatin 요법이 그전에 항암약물 치료를 덜 받은 환자에게 투여되었을 때 무진행 생존기간 이 길어지는 것으로 분석되었다. 하지만 나이, 호르몬 수용 체, HER2/neu 수용체, 방사선과 호르몬 치료의 병용여부 등 은 영향을 미치지 않았다. 전체 생존기간에 영향을 미치는 인자는 없거나 환자수가 작아서 통계적 분석이 불가능하였 다(Table 5).

\section{고 찰}

전이성 유방암에서 paclitaxel과 cisplatin을 병용한 연구는 몇몇 보고자에 의해 보고되었다. Wasserheit 등은 2상 임상 
시험에서, 42 명의 3 기와 4 기 유방암 환자들을 대상으로 일 차치료와 구제요법으로 paclitaxel과 cisplatin 병용 치료를 보고하였다. Paclitaxel $200 \mathrm{mg} / \mathrm{m}^{2}$ 24시간 정주와 cisplatin 75 $\mathrm{mg} / \mathrm{m}^{2}$ 을 3주 간격으로 투여하였고 G-CSF를 예방적으로 처 치하여 반응률 $52 \%$ 를 보고하였다. $68 \%$ 에서 4 도의 호중구 감소증이 있었고 신경독성이 주된 용량제한독성이었다 (10). 또한, 29 명의 환자들을 대상으로 하여 paclitaxel $90 \mathrm{mg} /$ $\mathrm{m}^{2}$ 과 cisplatin $60 \mathrm{mg} / \mathrm{m}^{2}$ 을 3시간 동안 2주 간격으로 투여한 $\mathrm{I} / \mathrm{II}$ 상 연구에서, $85 \%$ 의 반응률과 경미한 3 도 호중구 감소증 만 관찰하였음이 보고되었다(11). 반면, 또 다른 2상 임상시 험에서는 전에 항암제치료를 받았던 환자 16명을 대상으로 같은 방법으로 치료한 결과 $23 \%$ 의 반응률을 보고함으로써 전이성 유방암에 대한 구제치료로서 효과적이지 않다고 보 고하였다(12).

전이성 유방암에서 일차 약제로 $50 \%$ 정도의 반응률을 보 이는 cisplatin은 위에서 언급한 몇몇의 소규모의 연구를 제 외하곤 1990년 중반 이후로는 연구 결과가 보고되지 않고 있다. Paclitaxel은 투여시간, 용량 및 투여주기 등에 관한 많 은 연구가 진행되어 현재 유방암에서 $175 \mathrm{mg} / \mathrm{m}^{2}$ 을 3시간 동안 3주 간격으로 투여하는 것이 일반적인 치료이긴 하지 만 현재도 1 주 간격으로 투여하여 dose density를 높이는 방 법에 대한 연구가 활발히 진행 중이다 $(13,14)$. 본 연구는 비 록 24명을 대상으로 시행한 연구이지만, 3 주 간격으로 paclitaxel을 $175 \mathrm{mg} / \mathrm{m}^{2}$ 을 3시간 투여하여 cisplatin과 병용치료 한 결과 반응률이 $50 \%$ (9/18)로 이차적 항암제 치료로서는 비교적 우수한 반응률을 보였다.

그러나 본 연구에서는 방사선 치료와 호르몬 치료를 항 암제 치료와 동시에 진행하는 것이 허용되어 $33 \%$ (8/24)에 서 방사선 치료, $63 \%$ (15/24)에서 호르몬 치료를 동시에 받 았다. 방사선 치료는 골전이의 경우 통증완화를 위해 그리 고 호르몬 치료는 호르몬 수용체 양성인 경우와 항암치료 시작 당시 폐경인 환자에게 투여되었다. 최근, 항암제와 호 르몬 병용요법의 효과를 알아보기 위한 연구에 의하면, 항 암제와 호르몬제제 병용치료는 항암제 치료에 비해 뚜렷한 생존율 증가가 없음이 보고되었다(15).

Wasserheit 등이 시행한 2상 임상연구에서 paclitaxel 200 $\mathrm{mg} / \mathrm{m}^{2}$ 24시간 정주와 cisplatin $75 \mathrm{mg} / \mathrm{m}^{2}$ 을 3주 간격으로 투 여하였고 G-CSF를 예방적으로 처치하여 $68 \%$ 에서 호중구 감소가 있고 신경독성이 심했음을 보고하였으나(10). 본 연 구에서는 $20 \%$ 에서 $3 / 4$ 도의 백혈구 감소증을 보였다. 신경 독성도 주된 용량제한독성(dose-limiting toxicity)이 아니었 다. 이는 G-CSF의 예방적 사용에 기인하거나 paclitaxel의 용량 차이에 의함이라고 생각한다.

본 연구 결과, 전이성 유방암에서 paclitaxel과 cisplatin의
병용치료는 효능이 있고 안전하였다. 그러나, 본 연구는 24 명을 대상으로 한 소규모 연구이고, cisplatin으로 인한 오심, 구토 등으로 인해, 용량 강도가 paclitaxel 0.75 , cisplatin 0.63 로 순응도가 높지는 않았다. 특히 2명의 환자는(Fig. 2의 1, 13 번 환자) 각각 1 회와 2회 항암화학요법 후 오심, 구토로 더 이상 치료 원하지 않아 나머지 항암치료는 cisplatin을 제 외하고 paclitaxel 단독으로 투여되었다. 현재 docetaxel, paclitaxel 외에 gemcitabine, vinorelbine, capecitabine 등의 약제 들이 이차 항암 치료로서 연구되고 있다(16). 따라서 paclitaxel과 cisplatin의 병용치료는 높은 반응률을 고려한다면, 전이성 유방암의 보존적 치료의 한 방법으로는 제시할 수 있다.

\section{결 론}

과거에 항암제 치료를 받았던 진행성 혹은 전이성 유방 암 환자를 대상으로 paclitaxel과 cisplatin 병용 항암치료로 $50 \%$ 의 반응률과 6 개월의 진행정지기간을 유도하였다. 백 혈구 감소증이 가장 심한 부작용이었으나 G-CSF투여로 $20 \%$ 정도에서만 관찰되었고 치료와 관련된 사망은 없었다.

\section{REFERENCES}

1. Suh CI, Suh KA, Park SH, Chang HJ, Ko JW, Ahn DH. Annual report of the central cancer registry in Korea-1998. J Korean Cancer Assoc 2000;32(5):827-834

2. Early Breast Cancer Trialists' Collaborative Group. Polychemotherapy for early breast cancer: an overview of the randomised trials. Lancet 1998;352:930-942.

3. Nabholtz JM, Senn HJ, Bezwoda WR, Melnychuk D, Deschnes L, Douma J, Vandenberg TA, Rapoport B, Rosso R, TrilletLenoir V, Drbal J, Molino A, Nortier JWR, Richel DJ, Nagykalnai T, Siedlecki P, Wilking N, Genot JY, Hupperets PSGJ, Pannuti F, Skarlos D, Tomiak EM, Murawsky M, Alakl M, Riva A, Aapro M. Prospective randomized trial of docetaxel versus mitomycin plus vinblastine in patients with metastatic breast cancer progressing despite previous anthracyclinecontaining chemotherapy. 304 Study Group. J Clin Oncol 1999; 17:1413-1424.

4. Bishop JF, Dewar J, Toner GC, Smith J, Tattersall MHN, Olver IN, Ackland S, Kennedy I, Goldstein D, Gurney H, Walpole E, Levi J, Stephenson J, Canetta R. Initial paclitaxel improves outcome compared with CMFP combination chemotherapy as front-line therapy in untreated metastatic breast cancer. J Clin Oncol 1999;17:2355-2364.

5. Sledge GW Jr, Neuberg D, Ingle J, Martino S, Wood W. Phase III trial of doxorubicin vs. paclitaxel vs. doxorubicin+paclitaxel as first-line therapy for metastatic breast cancer: an intergroup trial. Proc Am Soc Clin Oncol 1997;16:1a(abst 2)

6. Neuberg D, Sledge GW Jr, Fettig J, Cella D, Wood W. Changes in quality of life (QOL) during induction therapy in patients enrolled in a randomized trial of Adriamycin, Taxol, and Adriamycin plus Taxol in metastatic breast cancer. Proc Am Soc Clin Oncol 1997;16:54a(abst 185). 
7. Paridaens R, Biganzoli L, Bruning P, Klijn JGM, Gamucci T, Houston S, Coleman R, Schachter J, Vreckem AV, Sylvester R, Awada A, Wildiers J, Piccart M. Paclitaxel versus doxorubicin as first-line single-agent chemotherapy for metastatic breast cancer: A European Organization for Research and Treatment of Cancer. J Clin Oncol 2000;14:724-733.

8. Crown JP. The Platinum Agents: A role in breast cancer treatment? Semin Oncol 2001;28 (1 Suppl 3):28-37.

9. Cocconi G, Bisagni G, Bacchi M, Boni C, Bartolucci R, Ceci G, Colozza MA, De Lisi V, Lottici R, Mosconi AM. Cisplatin and etoposide as first-line chemotherapy for metastatic breast carcinoma: a prospective randomized trial of the Italian Oncology Group for Clinical Research. J Clin Oncol 1991;9:664669.

10. Wasserheit C, Frazein A, Oratz R, Sorich J, Downey A, Hochster H, Chachoua A, Wernz J, Zeleniuch-Jacquotte A, Blum R, Speyer J. Phase II trial of paclitaxel and cisplatin in women with advanced breast cancer: an active regimen with limiting neurotoxicity. J Clin Oncol 1996;14:1993-1999.

11. Gelmon KA, O'Reilly SE, Tolcher AW, Campbell C, Bryce C, Ragaz J, Coppin C, Plenderleith IH, Ayers D, McDermott B, Nakashima L, Healey D, Onetto N. Phase I/II trial of biweekly paclitaxel and cisplatin in the treatment of metastatic breast cancer. J Clin Oncol 1996;14:1185-1191.
12. Sparano JA, Neuberg D, Glick JH, Robert NJ, Goldstein LJ, Sledge GW, Wood W. Phase II trial of biweekly paclitaxel and cisplatin in advanced breast carcinoma: an Eastern Cooperative Oncology Group study. J Clin Oncol 1997;15:1880-1884.

13. Sparano JA. Taxanes for breast cancer: an evidence-based review of randomized phase II and III trial. Clin Breast Cancer 2000;1:32-40.

14. Green MC, Buzdar AU, Smith T, Ibrahim NK, Valero V, Rosales M, Cristofanilli M, Booser DJ, Pusztai L, Rivera E, Theriault R, Carter C, Singletary SE, Kuerer HM, Hunt K, Strom E, Hortobagyi GN. Weekly paclitaxel followed by FAC as primary systemic chemotherapy of operable breast cancer improves pathologic complete remission rates when compared to every 3-week paclitaxel therapy followed by FAC therapy. Proc Am Soc Clin Oncol 2002(abstr 135);21:35a.

15. Sledge GW, Hu P, Falkson G, Tormey D, Abeloff M. Comparison of chemotherapy with chemohormonal therapy as first-line therapy for metastatic, hormone-sensitive breast cancer: An Eastern Cooperative Oncology Group Study. J Clin Oncol 2000;18:262-266.

16. Park JY, Kim C, Sohn JH, Kim YT, Rha SY, Jang WI, Kim GE, Chung HC. A phase II study of gemcitabine monotherapy in breast cancer patients refractory to anthracycline and taxane. Cancer Res Treat 2002;34:274-279. 